\title{
READINESS FOR LEARNER AUTONOMY OF PROSPECTIVE TEACHERS MINORING IN ENGLISH
}

\author{
Iryna Khalymon \\ Nizhyn Mykola Gogol State University, Nizhyn, Ukraine \\ irene.khalymon@gmail.com \\ Svitlana Shevchenko \\ Nizhyn Mykola Gogol State University, Nizhyn, Ukraine \\ svetusikndu@gmail.com
}

\begin{abstract}
Learner autonomy is one of the key factors in successful language teaching and learning, therefore teachers' task is to develop learners' autonomy. However, teachers can foster learners' autonomy only if they are autonomous learners themselves. The article reports findings of a survey study of the level of readiness for learner autonomy among prospective teachers minoring in English at Nizhyn Mykola Gogol State University in Ukraine. The data were gathered through a questionnaire, designed to investigate each learner's perceptions and beliefs in four domains associated with learner autonomy: willingness to take learning responsibilities, selfconfidence to learn autonomously, motivation to learn English, capacity to learn autonomously. The research indicated that the general level of the prospective teachers' learner autonomy is moderate though mean values fluctuate considerably from item to item. Thus, their motivation to study English and willingness to take learning responsibilities are on a high level, while their capacity and self-confidence to learn autonomously are moderate, with some items having means lying in the range that characterises a low level of learner autonomy. The implications of this study suggest that teacher trainers need to pay more attention to creating conditions in the classroom that will help prospective teachers become highly autonomous learners themselves.
\end{abstract}

Keywords: learner autonomy; readiness; prospective English language teacher; teacher trainer; language learning.

\section{Introduction}

Learner-centred approach in education has led to the emergence of the concept of learner autonomy, which has been in the centre of researchers' attention for a few decades. Learner autonomy is especially important in language learning because as Esch (1997) argues, language has specific features which need to be taken into consideration when we talk about autonomous language learning. Language learning is different from any other learning, say physics or geography, because language is used to describe and talk about our learning experience (p. 166).

Originally, learner autonomy in connection with language learning was defined by Holec (1981) as "the ability to take charge of one's learning" (p. 3). Little (1991) defines learner autonomy as essentially the matter of the learner's psychological relation to the process and content of learning, a capacity for detachment, critical reflection, decision-making and independent action (p. 4). Littlewood (1996) develops this point, describing autonomy as learner's ability and willingness to make and carry out the choices which govern his or her actions. He also suggests that this ability depends on possessing both knowledge about the alternatives from which choices have to be made and necessary skills for carrying out choices, while willingness depends on having both the motivation and confidence to take responsibility for the choices required (p. 428). As Sinclair (2000) observes, there seems to be almost universal acceptance of the development of autonomy as an important, general educational goal (p. 5), that is, teachers should help the learners in recognising their own ways of learning and enhance learners' capacity so that they can be ready for learning all through their lives.

Whether learner autonomy is promoted depends on whether teachers are autonomous learners themselves, because " $[t]$ he extent to and manner in which learner autonomy is promoted in language learning classrooms is influenced by teachers' beliefs about what autonomy actually is, its desirability and feasibility" (Borg \& Al-Busaidi, 2012, p. 6). Moreover, Little (1995) states that "learner autonomy and teacher autonomy are interdependent" (p. 179) and the teacher autonomy is "a prerequisite for the development of learner autonomy" (p. 178). He further argues that "language teachers are more likely to succeed in promoting learner autonomy if their own education has encouraged them to be autonomous" (p. 180). So, it is vital that English language teachers should be autonomous language learners, and teacher trainers should make sure that they foster their trainees' autonomy.

Before anything is done in this direction, it is necessary to collect some information about learners' existing attitudes and expectations (Scharle \& Szabo, 2000, p. 12), i.e. explore learners' readiness for autonomous learning. There have been quite a lot of researches in different countries investigating prospective teachers' level of learner autonomy and related issues (e.g., Balçıkanlı, 2010; Hoxha \& Tafani, 
2015; Tarhan and Erözden, 2008). Ukrainian researchers also pay some attention to the problem of learner autonomy, but they focus mostly on ways of fostering learner autonomy (Hahina, 2014; Haidar, 2015; Solomko, 2012; Zadorozhna, 2015) while the level of readiness for learner autonomy of prospective English language teachers remains out of focus.

That is why, the objectives of this study are to find out the level of readiness for learner autonomy of prospective English language teachers and to discuss the implications of the findings for teacher trainers.

\section{Method}

\section{Participants}

In order to explore the level of readiness for learner autonomy of prospective English language teachers, we have conducted a case study among the students who master English as their second speciality at the Philological Department of Nizhyn Mykola Gogol State University while majoring in the Ukrainian language and literature. This group was chosen for the research due to the fact that English as a second speciality is offered by a number of Ukrainian teacher-training institutions. Many graduates find employment as teachers of English so it is really important that they have the same language skills and competences as the prospective teachers who major in English. As these students have fewer classes of English and so their language learning experience is not as rich as of those who major in English, it is essential that they should be able to learn autonomously. Besides, for the research, we chose students who have studied at the university for more than two years as they are more experienced in learning English and are more likely to take their future occupation seriously.

\section{Instruments}

The study is based on quantitative research. The main research tool was the questionnaire aimed to find out the level of students' readiness for learner autonomy (Swatevarcharkul, 2008, p. 144). It is reported that the questionnaire has been piloted and its homogeneity and validity demonstrated by means of statistical tools. Thus, the questionnaire validity and reliability are 0.80 and 0.84 respectively (ibid., p. 50). Nevertheless, items 3, 8, 16, 28 in the questionnaire have been modified (negative statements have been changed into affirmative) to avoid ambiguity and misinterpretation.

The whole questionnaire contains 34 items, which are divided into four categories (or domains): items 1-7 refer to students' willingness to take learning responsibilities; items 8-13-to self-confidence to learn autonomously; items 14-23 - motivation to learn English; items 24-34 - capacity to learn autonomously. The respondents, however, were not informed of these categories.

As the aim of the research is to measure people's attitudes and beliefs, Likert Scale is used to collect the attitudinal data through getting people's reactions to statements. Students were asked to rate how much they agreed with each statement (strongly agree, agree, uncertain, disagree, strongly disagree). For scoring purposes, the statements were given weights of 5, 4, 3,2, 1 . The 'weights' are interpreted as follows: 5 means that learner autonomy readiness is very high, 4 - high, 3 - moderate, 2 - low, 1 - very low. Correspondingly, the evaluation criteria of the questionnaire are as follows: $1.00-1.50$ means that learner autonomy readiness is very low, 1.51-2.50 - low, 2.51-3.50 - moderate, 3.51-4.50 - high, 4.51-5.00 - very high.

\section{Data collection}

The questionnaire was completed anonymously in 2016 by 45 respondents studying in their $3^{\text {rd }}, 4^{\text {th }}$ and $5^{\text {th }}$ years $(10,11$ and 24 students respectively). The questionnaire was administered in the classroom under the teachers' supervision. The students spent about 15-20 minutes answering the questions.

\section{Results}

The survey response data were tabulated using Microsoft Excel 2010. To discover the general level of readiness for learner autonomy, the results of the 34-item questionnaire were analysed to find out mean score and standard deviation (columns ' $\mathrm{M}$ ' and 'SD' in the tables). Table 1 demonstrates the results of statistical analysis of the four examined domains which shows that the mean value for the whole questionnaire is 3.45 $(\mathrm{SD}=1.03)$. According to the criteria mentioned above this indicates that on the whole the prospective teachers' autonomy readiness level is moderate. However, the data on the categories vary considerably: their willingness to take learning responsibilities and motivation to learn English are on a high level, while their capacity and self-confidence to learn autonomously are on a moderate level. 
Table 1

Mean of each category and level of learner autonomy readiness

\begin{tabular}{|l|c|l|l|}
\hline \multicolumn{1}{|c|}{ Category } & M & \multicolumn{1}{|c|}{ SD } & \multicolumn{1}{|c|}{$\begin{array}{c}\text { Level of learner } \\
\text { autonomy readiness }\end{array}$} \\
\hline Willingness to take learning responsibilities & 3.51 & 1.05 & high \\
\hline Self-confidence to learn autonomously & 2.92 & 0.96 & moderate \\
\hline Motivation to learn English & 3.97 & 1.11 & high \\
\hline Capacity to learn autonomously & 3.41 & 0.99 & moderate \\
\hline Average & $\mathbf{3 . 4 5}$ & $\mathbf{1 . 0 3}$ & moderate \\
\hline
\end{tabular}

More detailed results are displayed in Tables 2 to 5. The first three columns of numbers present percentages of responses reduced to three categories: disagreement (options 'strongly disagree' and 'disagree', column 'Disagree' in the tables), uncertainty (option 'uncertain', column 'Uncertain') and agreement (options 'strongly agree' and 'agree', column 'Agree'). In relation to the first domain of learner autonomy, the result of the statistical tests concerning the mean of the students' answers is $3.51(\mathrm{SD}=1.05)$ which proves that students' willingness to take learning responsibilities is at a high level. Table 2 provides a detailed description of the means of students' answers regarding this category. We can see that more than half of the respondents agreed with the statements of most items (except items 1 and 3). The figure that attracts attention in this table is the mean for item 4 , which is the highest in this domain -3.76 (SD=0.90). It indicates that almost $70 \%$ of learners are pleased to take responsibility for their own learning. This assumption is supported by the data on item 2 which demonstrate that two thirds of the learners agree that they need to control their learning. Also, it can be inferred from the data in the table that more than half of the prospective teachers like to have some freedom in their learning determining what they want to learn both in and outside class (items 6 and 7). On the other hand, figures concerning item 1 (mean=3.24, $\mathrm{SD}=1.18$ ) contradict this optimistic deduction as they prove that only about $42 \%$ of the prospective teachers really feel responsible for their learning. Item 3 has equally low mean of $3.24(\mathrm{SD}=1.40)$ as item 1 and the figures give evidence that just about a third of the students like to seek additional knowledge outside class without any directions of the teacher, which indicates that learners are not eager to take initiative in their learning. The conclusion from this category of questions would seem to be that on the one hand, the respondents view themselves as being quite aware of the necessity to take learning responsibilities, but, on the other hand, they are not eager to do so in practice.

Table 2

Students' willingness to take learning responsibilities

\begin{tabular}{|c|c|c|c|c|c|}
\hline Item & Disagree & Uncertain & Agree & M & SD \\
\hline 1. I think learning is the sole responsibility of the learner. & 28.89 & 28.89 & 42.22 & 3.24 & 1.18 \\
\hline $\begin{array}{l}\text { 2. I need to control myself to do learning tasks that I think I } \\
\text { should do. }\end{array}$ & 13.33 & 20.00 & 66.66 & 3.64 & 0.92 \\
\hline $\begin{array}{l}\text { 3. I like to seek additional knowledge outside class if the } \\
\text { teacher does not tell me to do so. }\end{array}$ & 42.22 & 24.44 & 33.33 & 3.24 & 1.40 \\
\hline 4. I am pleased to take responsibility for my own learning. & 8.89 & 22.22 & 68.89 & 3.76 & 0.90 \\
\hline $\begin{array}{l}\text { 5. I am willing to evaluate my learning whether it is good or } \\
\text { bad. }\end{array}$ & 8.89 & 33.33 & 57.78 & 3.60 & 0.80 \\
\hline $\begin{array}{l}\text { 6. I am pleased to take part in determining the content I want } \\
\text { to learn in class. }\end{array}$ & 13.34 & 33.33 & 53.33 & 3.44 & 1.00 \\
\hline 7. I am pleased to decide what I will learn outside class. & 13.34 & 28.89 & 57.78 & 3.69 & 1.17 \\
\hline
\end{tabular}

The mean of the students' answers to items concerning the second domain - students' self-confidence to learn autonomously - is $2.92(\mathrm{SD}=0.96)$ (see Table 1), which indicates that this component of learner autonomy is not so well developed in the learners and is at the moderate level. The detailed results regarding this category demonstrated in Table 3 show that just item 13 "If I decide to learn anything, I can find time to study although I have something else to do" has mean above $3.50(\mathrm{SD}=0.98)$, which characterises a high level of learner autonomy. Other responses here reveal a certain lack of readiness for autonomy. Thus, in half of the items the means are below 3. The most striking responses are to items 8 and 9 that have the lowest mean value of 2.38 , i.e. according to the criteria mentioned above, the level of readiness for learner autonomy in these respects is low. As the table shows, $60 \%$ of respondents are not confident in their learning so they need constant support of the teacher (item 8) and almost 58\% cannot decide themselves what they should learn or what to do in and out of class (item 9). More than half of the learners chose option 
'uncertain' for item 12 "I think I am an effective autonomous learner, both in and out of class". Also, most students' time-management skills leave much to be desired, as only about one fifth of the prospective teachers are confident that they can manage their time well for learning. These findings indicate that learners rely on teachers greatly in many aspects of learning English. In other words, although the respondents are willing to take responsibility for their learning in the previous category, they are not confident enough that they can do it properly.

Table 3

Students' self-confidence to learn autonomously

\begin{tabular}{|c|c|c|c|c|c|}
\hline Item & Disagree & Uncertain & Agree & $\mathrm{M}$ & SD \\
\hline $\begin{array}{l}\text { 8. I am confident in my learning so I don't need constant } \\
\text { support of the teacher. }\end{array}$ & 60.00 & 28.89 & 11.11 & 2.38 & 1.00 \\
\hline $\begin{array}{l}\text { 9. I can decide myself what I should learn or what to do in } \\
\text { and out of class. }\end{array}$ & 57.78 & 26.67 & 15.55 & 2.38 & 1.04 \\
\hline $\begin{array}{l}\text { 10. I am confident that I can manage my time well for } \\
\text { learning. }\end{array}$ & 35.55 & 42.22 & 22.22 & 2.89 & 0.87 \\
\hline $\begin{array}{l}\text { 11. I am confident that I can make a good effort in seeking } \\
\text { knowledge I want to learn. }\end{array}$ & 17.78 & 35.56 & 46.66 & 3.36 & 1.06 \\
\hline $\begin{array}{l}\text { 12. I think I am an effective autonomous learner, both in and } \\
\text { out of class. }\end{array}$ & 26.67 & 51.11 & 22.23 & 3.02 & 0.83 \\
\hline $\begin{array}{l}\text { 13. If I decide to learn anything, I can find time to study } \\
\text { although I have something else to do. }\end{array}$ & 13.33 & 35.56 & 51.11 & 3.53 & 0.98 \\
\hline
\end{tabular}

The next category of the questionnaire concerns motivation to learn English. The mean of the students' answers in this domain is 3.97 ( $\mathrm{SD}=1.11$ ), which is the highest of all (see Table 1). A detailed description of the means of the students' answers regarding this category is provided in Table 4. As the analysis of the data shows, the mean for each item is above 3.5 and half of the values are above 4, which indicates that the level of the students' motivation to learn English is high. Few learners chose option 'uncertain' white answering this part of the questionnaire. Here we find the highest scores of the whole questionnaire, e.g. $82.22 \%$ of the respondents 'agree' and 'strongly agree' with the statement of item 15 "I like to learn English because it is interesting and important" which is rated 4.31 ( $\mathrm{SD}=1.24)$ (the highest mean of all). Also, $84.45 \%$ of the learners think that studying English can be important for them because it will allow them to meet and converse with more and varied people (item 18). The same number of respondents like to take part in English activities when they have free time (item 17). It can be inferred from these data that prospective teachers are intrinsically motivated to learn English. Figures concerning item 21 "I like to learn English because I will be able to get a job easily" and item 22 "I pay attention to learning English in order to get a good grade" (mean values are 4.00 and 3.67 respectively) suggest that the students also have a high level of extrinsic motivation to study English. We can conclude that teacher trainers while fostering prospective teachers' learner autonomy can rely on their high level of motivation as it is common knowledge that a motivated person in more likely to succeed in any activity.

Table 4

Students' motivation to learn English

\begin{tabular}{|c|c|c|c|c|c|}
\hline Item & Disagree & Uncertain & Agree & $\mathrm{M}$ & SD \\
\hline $\begin{array}{l}\text { 14. I like to have the chance to decide on what and how to } \\
\text { learn about English. }\end{array}$ & 13.33 & 17.78 & 68.89 & 3.67 & 0.99 \\
\hline $\begin{array}{l}\text { 15. I like to learn English because it is interesting and } \\
\text { important. }\end{array}$ & 11.11 & 6.67 & 82.22 & 4.31 & 1.24 \\
\hline 16. I enjoy learning English. & 17.77 & 8.89 & 73.33 & 3.96 & 1.41 \\
\hline $\begin{array}{l}\text { 17. I like to take part in English activities when I have free } \\
\text { time such as watching English movies or listening to English } \\
\text { songs or news. }\end{array}$ & 11.11 & 4.44 & 84.45 & 4.16 & 1.13 \\
\hline $\begin{array}{l}\text { 18. Studying English can be important for me because it will } \\
\text { allow me to meet and converse with more and varied people. }\end{array}$ & 6.67 & 8.89 & 84.45 & 4.20 & 1.07 \\
\hline $\begin{array}{l}\text { 19. Studying English can be important for me because I will } \\
\text { be able to participate more freely in the activities of other } \\
\text { cultural groups. }\end{array}$ & 8.89 & 13.33 & 77.78 & 3.93 & 1.06 \\
\hline
\end{tabular}

\section{(continued)}


Table 4

Students' motivation to learn English (continued)

\begin{tabular}{|c|c|c|c|c|c|}
\hline Item & Disagree & Uncertain & Agree & M & SD \\
\hline $\begin{array}{l}\text { 20. Studying English can be important for me because I will } \\
\text { need it for my future education. }\end{array}$ & 6.67 & 13.33 & 80.00 & 4.10 & 1.08 \\
\hline $\begin{array}{l}\text { 21. I like to learn English because I will be able to get a job } \\
\text { easily. }\end{array}$ & 6.66 & 13.33 & 80.00 & 4.00 & 0.89 \\
\hline $\begin{array}{l}\text { 22. I pay attention to learning English in order to get a good } \\
\text { grade. }\end{array}$ & 11.11 & 24.44 & 64.44 & 3.67 & 1.05 \\
\hline $\begin{array}{l}\text { 23. I think the teacher plays a crucial role in building } \\
\text { students' motivation to learn English, in and out of class }\end{array}$ & 15.55 & 26.67 & 57.78 & 3.73 & 1.18 \\
\hline
\end{tabular}

The final component of the questionnaire refers to the students' capacity to learn autonomously. The general mean of the respondents' answers is $3.41(\mathrm{SD}=0.99)$ (see Table 1) with most mean values lying in the range of 3.11-3.40 (see Table 5), which characterises their level of autonomy readiness in this respect as moderate. Some items, however, have higher means. This concerns the students' awareness of their learning weak points (item 26) and their attempts to improve on them (item 27), which shows a high level of readiness for learner autonomy in this aspect. Figures concerning items 32 (mean value=3.64, SD=1.04) and 25 (mean value $=3.53, \mathrm{SD}=1.02$ ) are also encouraging as they indicate that most respondents know where they can seek knowledge and can tell whether or not they are making learning progress. The students' weakest points in this domain are their ability to set their own learning objectives in class (item 24 with mean value $3.18, \mathrm{SD}=0.68$ ) and out of class (item 30 with mean value $3.22, \mathrm{SD}=0.99$ ) and their capability of finding appropriate learning methods and techniques for themselves (item 29 with mean value 3.11, $\mathrm{SD}=0.97$ ) as well as learning materials (item 31 with mean value $3.27, \mathrm{SD}=1.04$ ). Also, it should be pointed out that in many cases the respondents are uncertain about their answers in this category. For example, $64.44 \%$ of the prospective teachers are not sure whether they have the ability to set their own learning objectives in class (item 24); $46.67 \%$ are not certain if they are capable of telling about what they have learned (item 28); 44.44\% - whether they are capable of finding appropriate learning methods and techniques for themselves (item 29); 44.44\% - if they are capable of being totally responsible for their own learning (item 34). These data suggest that, on the one hand, teacher trainers can rely on the prospective teachers' strong points in this relation, on the other hand - that trainees lack important skills of autonomous learners and that teachers trainers should create conditions for developing these skills.

Table 5

Students' capacity to learn autonomously

\begin{tabular}{|c|c|c|c|c|c|}
\hline Item & Disagree & Uncertain & Agree & M & SD \\
\hline $\begin{array}{l}\text { 24. I have the ability to set my own learning objectives in } \\
\text { class. }\end{array}$ & 11.11 & 64.44 & 24.44 & 3.18 & 0.68 \\
\hline 25. I can tell whether or not I am making learning progress. & 11.11 & 33.33 & 55.56 & 3.53 & 1.02 \\
\hline 26. I know my learning weak points. & 6.66 & 28.89 & 64.44 & 3.78 & 0.99 \\
\hline 27. I try to improve on my learning weak points. & 11.11 & 22.22 & 66.67 & 3.67 & 0.97 \\
\hline 28. I am capable of telling about what I have learned. & 15.55 & 46.67 & 37.78 & 3.40 & 1.02 \\
\hline $\begin{array}{l}\text { 29. I am capable of finding appropriate learning methods and } \\
\text { techniques for myself. }\end{array}$ & 17.78 & 44.44 & 37.78 & 3.11 & 0.97 \\
\hline $\begin{array}{l}\text { 30. I have the ability to choose my outside class learning } \\
\text { objectives. }\end{array}$ & 24.44 & 31.11 & 44.45 & 3.22 & 0.99 \\
\hline 31. I am able to choose learning materials outside class. & 20.00 & 31.11 & 48.89 & 3.27 & 1.04 \\
\hline 32. I know where I can seek knowledge. & 17.78 & 17.78 & 64.44 & 3.64 & 1.04 \\
\hline $\begin{array}{l}\text { 33. I can evaluate by myself whether my learning is good or } \\
\text { bad. }\end{array}$ & 13.33 & 37.78 & 48.89 & 3.40 & 1.18 \\
\hline $\begin{array}{l}\text { 34. I am capable of being totally responsible for my own } \\
\text { learning. }\end{array}$ & 13.34 & 44.44 & 42.22 & 3.33 & 0.99 \\
\hline
\end{tabular}


Another figure in the tables that is worth mentioning is the standard deviation. A low standard deviation indicates that the data points tend to be close to the mean of the set, while a high standard deviation shows that the data points are spread out over a wider range of values. As it is clear from the tables above, most values of standard deviation lie in the range $0.85-1.10$, i.e. the answers are more or less homogeneous. The lowest values of standard deviation are found in the categories having the lowest mean values - students' capacity and self-confidence to learn autonomously. This seems to be one more proof that these aspects of learner autonomy are not so well developed in most learners.

\section{Discussion}

Having analysed the results of the investigation, we can say that, on the one hand, it is encouraging for teacher trainers to know that the trainees are generally willing to take responsibility for their learning and are quite highly motivated to learn English. On the other hand, the study reveals that the students seem to hold many views and beliefs that contradict the move towards greater autonomy. Thus, the majority (about 66\%) are not likely to seek additional knowledge outside class on their own initiative (item 3); about 58\% of respondents cannot decide themselves what they should learn or what to do in and out of class and almost $27 \%$ or are not sure that they are able to do this (item 9); two thirds of the prospective teachers are uncertain whether they are able to set their own learning objectives in class (item 24).

The obtained results tell us something about the current practices in language teaching and teacher training. Thus, we can assume that teachers and teacher trainers have been quite successful in building their learners' motivation. This assumption is supported by the data on the students' motivation on the whole and the figures concerning item 23 indicating that almost 58\% of them believe that it the teacher who is responsible for building learner's motivation. However, judging by the fact that the respondents, being adult learners with quite a long experience in learning English (ten years on average), have a moderate level of learner autonomy, we can infer that fostering learner autonomy has not become a common practice either at schools or universities and teacher trainers should pay more attention to this aspect.

Besides, we can see that there exists a gap between the students' wishes and practices. On the one hand, as we have argued above, they are highly motivated to learn English and willing to take learning responsibilities. On the other hand, prospective English language teachers do not have enough selfconfidence and capacity to learn autonomously, which is supported by the facts that $60 \%$ of learners need constant support of the teacher (item 8 of the questionnaire) and that about half of the students are not sure whether they are effective autonomous learners, both in and out of class (item 12). Therefore, in spite of the fact that the respondents are expected to be experienced language learners, they still need substantial support from teacher trainers.

The findings of the research also contribute to a better understanding of students' beliefs and needs. Thus, the figures indicate that prospective teachers value freedom and opportunities to direct their own learning, therefore, teacher trainers should create appropriate learning environment. On the other hand, it can be inferred from the obtained data that most of them are not confident in their learning therefore they need constant support of the trainers. For instance, they need some guidance in setting their learning objectives, finding appropriate learning methods and techniques for themselves and assessing the results. This implies that teacher trainers should develop students' confidence providing the necessary support in the form of learning strategies which would help them become more independent in their learning.

The findings of this case study go in line with the results reported by researchers from other countries (Balçıkanlı, 2010; Hoxha \& Tafani, 2015; Tarhan and Erözden, 2008): prospective teachers view learner autonomy generally positively, though they have certain difficulties being autonomous learners. That is why we cannot but agree with Benson (2003) who states that teachers should create the atmosphere and conditions in which learners will feel encouraged to develop the autonomy they already have (p. 305).

\section{Conclusions}

This study was aimed at investigating the level of prospective English language teachers' readiness for learner autonomy. It has covered four dimensions - students' willingness to take learning responsibilities, self-confidence to learn autonomously, motivation to learn English and capacity to learn autonomously. The results show that prospective teachers have some basic level of learner autonomy, so teacher trainers do not have to start from scratch. The respondents' capacity and self-confidence to learn autonomously are moderate, which implies that students are still dependent on their teachers and need some guidance to help them become more confident learners, capable to learn autonomously. However, they are highly motivated to learn English and are willing to take learning responsibilities, and, as the proverb says, where there is a will, there is a way. To provide gradual movement towards greater learners' independence, teacher trainers should seek ways to encourage conscious reflection on the learning process. Making the students aware of their 
level of learner autonomy, their strengths and weaknesses can be the first step in this direction.

This study is not comprehensive or extensive. There are many more dimensions yet to be explored. They include the factors such as the learner's approaches to studying, the correlation between learner autonomy level and learning style, the ways to foster prospective teachers' learner autonomy, teacher trainers' views and beliefs concerning learner autonomy.

\section{References:}

Balçıkanl, C. (2010). Learner autonomy in language learning: student teachers' beliefs. Australian Journal of Teacher Education, 35(1), 90-103. http://dx.doi.org/10.14221/ajte.2010v35n1.8

Benson, P. (2003). Learner autonomy in the classroom. In Nunan, D (Ed), Practical English language teaching (pp. 289-308). New York: McGraw Hill.

Borg, S. \& Al-Busaidi, S. (2012). Learner autonomy: English language teachers' beliefs and practices. London: British Council.

Esch, E. (1997). Learner training for autonomous language learning. In Benson P. \& Voller P. (Eds.) Autonomy and independence in language learning (pp.164-176). London: Longman.

Hahina, N.V. (2014). Umovy rozvytku navchalnoi avtonomii studentiv VNZ [Developing learner autonomy in higher educational institutions]. Visnyk Chernihivskoho natsionalnoho pedahohichnoho universytetu. Seriia: Pedahohichni nauky, 117, 309311. Retrieved 7 July, 2016, from http://ir.stu.cn.ua/handle/123456789/5388?show=full

Haidar, M. M. (2015). Vstanovlennia avtonomii u studentiv-filolohiv u navchanni pysma za dopomohoiu proektnoho metodu [Developing autonomy of students-philologists while teaching writing by means of project method]. Visnyk Dnipropetrovskoho universytetu imeni Alfreda Nobelia. Seriia: Pedahohika i psykholohiia, 1, 204-209. Retrieved 7 July, 2016, from http://nbuv.gov.ua/UJRN/vduep_2015_1_33

Holec, H. (1981). Autonomy in foreign language learning. Oxford: Pergamon.

Hoxha, M. \& Tafani, V. (2015) Promoting Learner Autonomy in Pre-service Teacher Education. Anglisticum Journal (IJLLIS), 4 (9), 14-22. Retrieved 10 May, 2016, from http://anglisticum.aassee.eu/index.php/Anglisticum/article/view/1196

Little, D. (1991). Learner autonomy: Definitions, Issues, Problems. Dublin: Authentic.

Little, D. (1995). Learning as dialogue: The dependence of learner autonomy on teacher autonomy. System, 23 (2), $175-182$. https://doi.org/10.1016/0346-251x(95)00006-6

Littlewood, W. (1996). "Autonomy": an anatomy and a framework. System, 24(4), 427-435. https://doi.org/10.1016/s0346$251 \times(96) 00039-5$

Scharle, A. \& Szabo, A. (2000). Learner Autonomy: A guide for developing learner responsibility. Cambridge: Cambridge University Press.

Sinclair, B. (2000). Learner autonomy: The next phase. In Mcgrath, I, Sinclair , B \& Lamb, T (Eds), Learner autonomy, teacher autonomy: Future directions (pp. 15-23). London: Longman.

Solomko, S. (2012). Avtonomiia yak osnova samostiinoi roboty z inozemnoi movy studentiv nemovnykh spetsialnostei. [Autonomy as the basis of self-study work in foreign languages for students of nonlinguistic specialities] Visnyk Kyivskoho natsionalnoho linhvistychnoho universytetu. Seriia Pedahohika ta Psykholohiia, 21. Retrieved 7 July, 2016, from http://visnyk-pedagogy.knlu.kiev.ua/article/download/69292/64534

Swatevarcharkul, R. (2008). An investigation on readiness for learner autonomy, approaches to learning of tertiary students and the roles of English language teachers in enhancing learner autonomy in higher education: Research report. Retrieved 21 March, 2016, from http://libdoc.dpu.ac.th/research/134463.pdf

Tarhan, B. \& Erözden, A. (2008). Learner Autonomy and Trainee Teachers' Readiness for Self-Directed Learning. Boğaziçi Üniversitesi Eğitim Dergisi, 25 (1). Retrieved 15 July, 2016, from http://dergipark.gov.tr/buje/issue/3827/51421

Zadorozhna, I. P. (2015). Rozvytok avtonomii studentiv movnykh spetsialnostei u protsesi vyvchennia fakhovykh dystsyplin [Developing autonomy of students specialising in linguistics in the process of studying required courses]. Visnyk Chernihivskoho natsionalnoho pedahohichnoho universytetu. Seriia: Pedahohichni nauky, 131, 60-64. Retrieved 7 July, 2016, from http://nbuv.gov.ua/UJRN/VchdpuP_2015_131_16 